\title{
O CORPO NO ESPAÇO URBANO: ENTRE O VIGIAR, O PUNIR E O SIGNIFICAR
}

\author{
Maria Cleci Venturini ${ }^{*}$ \\ Universidade Estadual do Centro-Oeste \\ Departamento de Letras \\ Guarapuava, PR, Brasil
}

\section{Marilda Aparecida Lachovski ${ }^{* *}$ \\ Rede Estadual de Ensino}

\begin{abstract}
Resumo: O corpo, como objeto discursivo, é uma materialidade significante, pela qual retornam e ressoam memórias e discursos, instaurando processos de identificação. Neste sentido, pensa-se nas formas como o corpo vem sendo representado e lido, no espaço urbano, como uma textualidade. Faz-se isso por meio de dois olhares teóricos: o de Foucault e o de Pêcheux, ressaltando que o discurso constitui o ponto de encontro entre os dois. De um lado, atenta-se para o corpo vigiado e punido e para uma sociedade coercitiva, que se autoriza a fazer justiça e, de outro, para a ideologia que naturaliza o vigiar, o punir e as memórias que significam as práticas discursivas em torno do "fazer" justiça, do julgar e do condenar. Para isso, recorta-se a capa da revista Veja (fevereiro de 2014), tendo em vista o corpo vigiado e punido e o corpo que significa pela memória e pela ideologia em uma sociedade que se representa como justiceira, mas nem sempre justa.
\end{abstract}

Palavras-chave: Discurso. Corpo. Historicidade. Memória. Poder.

\section{INTRODUÇÃO}

O centro deste artigo é o corpo, no espaço urbano, como objeto discursivo, recortando-se três instâncias: o vigiar, o punir e o significar. Lançamos nosso olhar sobre este objeto textualizado por meio do texto-imagem que circulou, na capa da revista Veja, em fevereiro de 2014, dando visibilidade a uma sociedade que continua a vigiar e a punir. Essa legitimidade ocorre pelo poder, conforme Foucault (2008), e por memórias que retornam e sustentam o discurso da atualidade pela ideologia, conforme Pêcheux (1999, 2009). Com isso, instauram efeitos de evidência, pela inscrição do acontecimento em espaços de memória, funcionando como "o sempre já aí da interpelação ideológica que fornece/impõe a 'realidade' e o seu 'sentido' sob a forma da universalidade." (PÊCHEUX, 2009, p. 151).

Vale destacar, entretanto, que as condições de produção em torno das punições e das prisões pela política do corpo, trabalhadas por Foucault, são distintas do castigo

\footnotetext{
* Professora Adjunta do Departamento de Letras da UNICENTRO e do Programa de Pós-graduação em Letras. Bolsista produtividade da Fundação Araucária. E-mail: mariacleciventurini@gmail.com

** Mestre em Letras (PPGL da UNICENTRO). Professora da Rede Estadual de Ensino. E-mail: proffmarilda@hotmail.com
} 
imputado a um adolescente de 15 anos, acusado de roubo, devido às determinações dadas pela formação social e por seu funcionamento. Nosso objetivo é verificar quais os efeitos de sentido em torno da materialidade em tela; para isso, buscamos ancoragem em Pêcheux e nos teóricos que praticam a teoria do discurso com vistas a pensar como o corpo significa, considerando os pressupostos teóricos foucaultianos. Sinalizamos, entretanto, que na prática discursiva Foucault e Pêcheux percorrem caminhos que nem sempre se encontram. Para o primeiro, a entrada na ordem do discurso acontece pelo saber e pelo poder; para o segundo, pela ideologia e pelo inconsciente. Há outras diferenças importantes, dentre elas a concepção de sujeito e a teorização do discurso, que não foi a preocupação de Foucault. Pêcheux é o fundador da teoria do discurso, disciplina de entremeio entre o materialismo histórico, a psicanálise e a linguística. De acordo com Maldidier (2003, p. 94-95), Pêcheux avançou no estruturalismo político e "encontrou intelectualmente Foucault, Lacan e mesmo Derrida", especialmente quando de sua autocrítica.

Interessa-nos, neste texto, o discurso que perpassa a obra de Pêcheux e de Foucault e dá visibilidade ao funcionamento de um poder exercido sobre os que são punidos; "de uma maneira mais geral sobre os que são vigiados, treinados e corrigidos". É importante destacar que "a necessidade (desejo) de aparência, veículo de disjunções e categorizações lógicas: essa necessidade de 'um mundo semanticamente normal', isto é, normatizado, começa com a relação de cada um com seu próprio corpo.” (PÊCHEUX, 2002, p. 34). Entendemos a punição a partir do corpo, como um modo de "fazer crer pelo ver" . Desse modo, escapar à norma ou praticar qualquer ato que fuja à normalidade ou seja considerado ilícito é passível de punição; na materialidade significante em análise, os algozes são os próprios cidadãos.

Analisamos o mesmo objeto a partir de duas frentes. Pela primeira, buscamos investigar como os corpos são vigiados e punidos pelos mecanismos do poder e do saber que sustentam e legitimam práticas; pela segunda, colocamos em suspenso o indivíduo interpelado em sujeito pela ideologia e atravessado pelo inconsciente. Propomos percorrer, neste trabalho, esses dois caminhos, sendo que um centra-se na formação social que vigia e pune e outro, em que esse vigiar e esse punir constituem-se como práticas normatizadas pelo funcionamento da ideologia, decorrendo disso a instauração de evidências que constroem, como defendeu Foucault (2004a), valores de verdade. Como espaço de produção de efeitos de sentido em discursos efetivamente realizados, analisamos a capa da revista Veja de fevereiro de 2014, na qual ressoam discursos e memórias de punição e de castigo impostos sobre os corpos, em outros espaços e temporalidades, significando diferentemente, na atualidade. Destacamos, também, o modo como o discurso na/pela materialidade recortada, em torno da punição e do castigo sobre o corpo, no espaço urbano do Rio de Janeiro, instaura efeitos de sentido, perguntando pelos mecanismos discursivos responsáveis por esses efeitos.

\footnotetext{
${ }^{1}$ Esse mecanismo argumentativo foi trabalhado em Venturini (2009) em relação ao modo como a cidade de Cruz Alta se constitui como "a terra de Erico Verissimo", mostrando materialidades que 'evidenciam' que ele era e se orgulhava de ser cruz-altense "filho desta terra". Essa evidência sustenta-se, sobremaneira, pela placa que identifica a casa do escritor, onde funciona o museu que 'guarda' suas memórias. Certeau (1994, p. 178) mostra esse funcionamento quando trata da cidade e do modo como se constituem 'valores de verdade', que instauram portanto, verdades.
} 
Para Foucault (2004a, p. 8-9), "em toda sociedade a produção do discurso é ao mesmo tempo controlada, selecionada, organizada e redistribuída por certo número de procedimentos que têm por função conjurar seus poderes e perigos, dominar seu acontecimento aleatório, esquivar sua pesada e temível materialidade." Para Pêcheux (2009, p. 124), as práticas têm como centro o sujeito, que se constitui alicerçado na tese althusseriana, segundo a qual "o indivíduo é interpelado como sujeito (livre) para livremente submeter-se às ordens do Sujeito, para aceitar, portanto (livremente), sua submissão".

A sustentação teórica é a Análise de Discurso, a partir de discussões propostas por Foucault e por Pêcheux, e por pesquisadores que trabalham com o discurso. Centramonos nas questões do corpo e nos discursos que retornam de outros tempos, sobremaneira em torno do que faz parte da obra foucaultiana, em que são discutidas as questões de poder e de punição. Esse retorno sinaliza para o funcionamento da memória e para os modos como sujeitos e discursos entram 'na ordem do discursivo', legitimando e reforçando práticas coercitivas pela inscrição em um determinado contexto sóciohistórico e em uma determinada formação discursiva. Assim, como no período abarcado por Foucault, em sua obra, o vigiar e o punir continuam sendo praticados pelas instituições, as quais fazem, muitas vezes, justiça com as próprias mãos de modo semelhante ao que ocorre na materialidade significante que constitui o corpus de análise, em que a população, pautada no desejo de punir, de julgar e de supliciar, arroga-se o direito e/ou o dever de 'fazer justiça', para que crimes praticados sirvam de exemplo para os demais sujeitos.

\section{FOUCAULT E PÊCHEUX: DISCURSO, CORPO E IDEOLOGIA}

Tratamos, nesse artigo, do corpo como objeto discursivo a partir de Foucault, mas não podemos deixar de trazer Courtine (2009), Leandro Ferreira (2013) e, também, Pêcheux e Orlandi. Isso porque enfocamos o vigiar e o punir de um lado e o significar o corpo como textualidade, de outro. Courtine (2009, p. 7), em trabalho sobre a história do corpo, pergunta como é que o corpo se tornou, em nossos dias, um objeto de investigação histórica. Essa pergunta, quando relacionada a um corpus discursivo, suscita outra questão, qual seja: como é que o corpo se tornou uma textualidade passível de ser analisada, podendo ser tomada como corpus discursivo?

Segundo Courtine (2009, p. 7), "o século XX inventou teoricamente o corpo". A psicanálise foi o campo disciplinar que, a partir de Freud, decifrou a histeria e destacou que o inconsciente fala através do corpo, abrindo espaço para questões em torno das somatizações e da imagem do corpo na constituição do sujeito. $\mathrm{O}$ segundo marco em relação ao corpo, de acordo com o mesmo autor, ocorreu durante a Primeira Guerra Mundial, em que Marcel Mauss viu a infantaria britânica desfilar e percebeu que ela fazia uso de uma técnica corporal, o que permitiu construir hipóteses em torno das "maneiras como os homens sabem servir-se do seu corpo" (COURTINE, 2009, p. 8).

O terceiro marco tem relação com o corpo e com "os primeiros papéis nos movimentos individualistas e igualitaristas de protestos contra o peso das hierarquias 
culturais, políticas e sociais, herdadas do passado" (COURTINE, 2009, p. 8-9). Dentre esses movimentos destacam-se as mulheres, no início dos anos 1970 com o grito de protesto: "nosso corpo nos pertence". Os homossexuais juntaram-se às mulheres, pois "[...] o corpo foi investido no contexto das lutas travadas pelos direitos das minorias no decorrer da década de 1970: um lugar importante da repressão, um instrumento crucial de libertação, a promessa de uma revolução." (COURTINE, 2009, p. 9).

A noção de discurso postulada por Foucault (2004a) é de que este funciona como um jogo estratégico e polêmico; como espaço habitado pela articulação entre saber e poder. A produção de um discurso gerador de poder, no entanto, é controlada, selecionada, gerenciada e redistribuída por mecanismos que determinam a produção e circulação desses discursos. São as condições de possibilidade desses discursos que interessam a Foucault. E para compreender o modo como elas funcionam nas práticas dos sujeitos, Foucault (2004, p. 24) refere-se ao conceito de enunciado como "unidade elementar do discurso". O autor defende que não há existência de frases, proposições e ato de linguagem se não houver o enunciado, o qual não funciona apenas como uma unidade. Ele é uma "função que cruza um domínio de estruturas e de unidades possíveis e que faz com que apareçam, com conteúdos concretos, no tempo e no espaço", os dizeres, (FOUCAULT, 2010, p. 24).

Assim, não há modos de produção de um enunciado na dicotomia verdadeiro e falso, já que todos eles possuem condições de produção específicas, significando de um modo e não de outro, nessas condições e não em outras. E, se o discurso é heterogêneo, múltiplo e aberto a outros discursos que o circundam e o constituem, mostrando que nem tudo se pode dizer, há uma memória do dizer que autoriza ou não a produção desses enunciados e a possibilidade de sua reatualização em função daquilo que foi dito antes, em outras circunstâncias de enunciação. Pêcheux (2009, p.151) designa de pré-construído "o que corresponde ao sempre-já-aí da interpelação ideológica que fornece-impõe 'a realidade' e seu 'sentido' sob a forma da universalidade (o 'mundo das coisas')", essa memória.

A imposição da realidade demanda que se mobilize a noção de formação discursiva e de memória discursiva, tal como trabalhada por Foucault (2010) e Pêcheux (2009). Foucault (2010, p. 43) define a formação discursiva como um sistema de dispersão, descrito em certo número de enunciados no regime de repetibilidade, a que eles estão submetidos. A formação discursiva, nessa perspectiva, abarca todos os enunciados já ditos e esquecidos em uma enunciação, presentificados, transformados e reatualizados, segundo as redes de memória a que esses enunciados se filiam. Para Pêcheux (2009, p. 197), a formação discursiva é "o lugar de um trabalho de reconfiguração que constitui, segundo o caso, um trabalho de recobrimento-reprodução-reinscrição ou um trabalho politicamente e/ou cientificamente produtivo". Ela determina, segundo esse autor, o que pode ou deve ser dito a partir das posições que os sujeitos ocupam na formação social e de suas filiações ideológicas. E, devido a essa definição, sinaliza que nem tudo pode ser dito, e o sentido sempre pode ser outro, mas inscrito e filiado a essas redes, às formações e memórias discursivas.

Desse modo, não há enunciado que tenha origem desarticulada da ação humana na linguagem, na operação de práticas discursivas, das condições de sua produção e de 
sujeitos que ocupam uma determinada posição sócio-histórica. Isso faz com que se desloque a própria noção de sujeito, que se constitui pela heterogeneidade, pela divisão porque se significa na relação sujeito/língua/história. O sujeito, dependendo da posição que ocupa, é também descontínuo e desliza, discursivamente, para outras posições, produzindo outros discursos autorizados ou não, pela sua inscrição em distintas formações discursivas (FDs). Nas FDs, segundo Pêcheux (2009), o sujeito se identifica ou se contraidentifica, instaurando a resistência e a crítica, mas somente o afastamento vai promover a desidentificação que, de acordo com Indursky (2008), sinaliza para o 'um', ilusório efeito de liberdade do sujeito.

Diferentemente de Pêcheux, Foucault (2010) pensa o sujeito e o dizer por trajetos discursivos, permeados por relações entre os dizeres e os saberes, as práticas discursivas e as ações dos sujeitos na história dos saberes. Nesse sentido, os dizeres e saberes se inscrevem em FDs, que permitem ou não que esses discursos sejam produzidos, tenham um ou outro sentido e se inscrevam em um determinado espaço e tempo que, como elementos históricos, constituem o sujeito em suas práticas. O discurso, para Foucault, não é, como na psicanálise, "aquilo que manifesta (ou oculta) o desejo; é também, aquilo que é o objeto do desejo". Porque enfoca o poder e não a ideologia e o inconsciente, Foucault acrescenta que o poder "não é simplesmente aquilo que traduz as lutas ou os sistemas de dominação, mas aquilo por que, pelo que se luta, o poder do qual nos queremos apoderar." (FOUCAULT, 2004a, p. 10). Define-se, assim, a mola mestra de suas obras: a relação poder/saber/dizer que rege as discussões nas três fases de seus escritos e ditos.

Para Foucault (2004a), a análise desses procedimentos discursivos considera os modos de interdição e de controle que vigiam a descontinuidade, a pluralidade e a dispersão dos sujeitos. Neste sentido, segundo Foucault (2004a, p. 9), "sabe-se bem que não se tem o direito de dizer tudo, que não se pode falar de tudo em qualquer circunstância, que qualquer um, enfim, não pode falar de qualquer coisa". Para ele se cruzam três interdições: o tabu do objeto, o ritual da circunstância, o direito privilegiado ou exclusivo do sujeito que fala. No entanto, uma não funciona isolada da outra, ao contrário, se cruzam, se reforçam ou se compensam, formando o que Pêcheux (2009, p. 54) chama de redes de memória, "dando lugar a filiações identificadoras". É nessa concepção de sujeito e seu funcionamento que Foucault e Pêcheux se distanciam, pois para um o que determina o dizer é a interdição e para o outro, o dizer é determinado por filiações ideológicas. As diferenças entre Pêcheux e Foucault se mantiveram, pois apesar de o primeiro ter retificado a sua teoria, a sua grande questão sempre foi em torno da contradição em relação à interpelação do sujeito e da linguagem em discurso.

Essa diferença se amplia e se explica pela fundação da teoria discursiva por Pêcheux (2009) a partir de dois eixos: o da interpelação do indivíduo sujeito e o seu atravessamento pelo inconsciente, dando visibilidade ao modo como os corpos significam, não só pela ideologia e pelo inconsciente, mas também pela memória, que funciona e significa pelos discursos que retornam. Na materialidade significante analisada neste texto o corpo constitui efeitos de sentidos por práticas coercitivas e punitivas que podem ser analisadas pela teoria pêcheuxtiana e, também, pelos preceitos foucaultianos, deste último ressaltando-se o corpo e os sentidos que instaura. 
Pêcheux (2009, p. 278) destaca que "a ordem do inconsciente não coincide com a da ideologia, o recalque não se identifica nem com o assujeitamento, nem com a repressão, mas isso não significa que a ideologia deva ser pensada sem referência ao registro inconsciente". Com isso, o autor retoma a interpelação ideológica plena, em que o sujeito identificava-se com a forma-sujeito, sinalizando que a ideologia é um ritual com falhas, ressoando o discurso lacaniano, segundo o qual 'só há causa daquilo que falha'. Assim, Pêcheux (2009, p. 277) identifica, no platonismo, a falta radical do inconsciente, "isto é, a causa que determina o sujeito exatamente onde o efeito de interpelação o captura; o que falta é essa causa, na medida em que ela 'se manifesta' incessantemente' e sob mil formas (o lapso, o ato falho, etc.), no próprio sujeito”. É assim que ideologia e inconsciente funcionam na teoria discursiva, especialmente no que se refere ao político e à disciplinarização da Análise de Discurso, quando de sua autocrítica no que chamou de 'inverno francês'.

Como a materialidade significante em análise abarca também o não verbal, discutimos a questão do silênco, que significa nas imagens, e nos ancoramos em Orlandi (2002, p. 31) para quem o silêncio é fundante, significante para o sujeito, "é o real do discurso" porque o homem está condenado a significar com ou sem palavras. Isso, de acordo com a autora, incomoda aqueles que trabalham com a linguagem. Esse posicionamento abre espaço para trabalhar também com as imagens, não em sua opacidade, mas no modo como significam pela memória e pela repetição. Desse modo, "[...] a linguagem supõe [...] a transformação da matéria significante por excelência (silêncio) em significados apreensíveis, verbalizáveis. Matéria e formas. A significação é um movimento. Errância do sujeito, errância dos sentidos...” (ORLANDI, 2002, p. 35).

Desse modo, a interpretação do corpo como objeto discursivo ocorre, também, pela leitura das imagens e pelo que elas deixam de dizer, mas dizem, por meio do silêncio e da sua opacidade, visto que a imagem, como discurso, significa, como já sinalizamos, pela memória, pela ideologia e pelo silêncio.

\section{O PODER E O SABER: SUJEITO E SENTIDO}

As materialidades analisadas, neste trabalho, demandam que se trate, além da ideologia e do inconsciente, também do saber e do poder. Por isso, trazemos Foucault que, em seus escritos (e ditos) não se preocupa em definir o poder, mas em entender como esse poder, ou melhor, os poderes são exercidos no seio das sociedades, nas relações humanas, na política, na economia, na história. Para ele é importante analisar os mecanismos de poder e os dispositivos que sustentam esse poder nas sociedades. Nesse funcionamento, o poder não é imutável, centrado ou homogêneo, é, antes de tudo, transitório, posto em prática. Em sua obra Em defesa da sociedade (2002, p. 21), o autor destaca que o poder "não se troca, não se dá, nem se retoma, mas que ele se exerce e só existe em ato". Logo, não há poder sem que haja relações, práticas humanas que o possibilitem, que demandem a sua existência. Nesse sentido, ainda acrescenta que "não é primeiramente manutenção e recondução das relações econômicas, mas em si mesmo, primariamente, uma relação de força." (FOUCAULT, 2002, p. 21). 
O poder centralizado na figura do soberano é dessacralizado, transmutado e multiplicado; segundo Foucault (2004a), é exercido em todas as relações humanas, não havendo, portanto, uma dominação, mas formas múltiplas de dominação que podem ser exercidas no interior das sociedades. Nesse sentido, o poder, mesmo que atravessado pelas instituições que o regulam, vai além das regras que o determinam, e se prolonga nas práticas do homem. Portanto, como objeto do desejo de poder, os discursos também são definidores daquilo que Foucault (2004a) denomina "vontade de verdade"; nesse sentido defende que:

[...] essa vontade de verdade, como os outros sistemas de exclusão, apóia-se sobre um suporte institucional: é ao mesmo tempo reforçada e reconduzida por todo um compacto conjunto de práticas [...]. Mas ela é também reconduzida, mais profundamente sem dúvida, pelo modo como o saber é aplicado em uma sociedade, como é valorizado, distribuído, repartido e de certo modo atribuído. (FOUCAULT, 2004a, p. 17).

A vontade de verdade importa na medida em que não é objetivo principal de Foucault a noção de poder, mas sim a concepção de sujeito. Esse sujeito é, em suas análises, o lugar da produção de poderes, saberes e dizeres, portanto, a materialidade das condições na produção de enunciados e discursos. Assim, Foucault (1995, p. 231) propõese a estudar a objetivação do sujeito nas "práticas divisoras", nas quais o ele "é dividido no seu interior e em relação aos outros". Esse processo de objetivação possibilita a separação entre aquilo que o constitui e aquilo que o desconstrói, como aquilo que é, e aquilo que lhe falta. Como exemplos, mostra a contraposição dos pares dicotômicos: louco/são, doente/sadio, criminosos/“bons meninos". Essas divisões, de acordo com Foucault, categorizam os indivíduos, nomeando-os e imputando-lhes marcas de individualidade, e ao mesmo tempo impõem a eles uma "lei de verdade", sujeitando-os. Nesse sentido:

[...] é uma forma de poder que faz dos indivíduos sujeitos. Há dois significados para a palavra sujeito: sujeito a alguém pelo controle e dependência, e preso à sua própria identidade por uma consciência ou autoconhecimento. Ambos sugerem uma forma de poder que subjuga e torna sujeito a. (FOUCAULT, 1995, p. 235).

Nesse funcionamento, ocorre a regulização da exigência de verdade, que permite a análise da materialidade significante, o corpo do sujeito, enquanto texto. Assim, o corpo, como construção simbólica, é textualizado pelos sujeitos que, pela maneira como o fazem, significam de modos diferentes, inscrevendo-se como seres simbólicos e políticos. São esses corpos "fora do lugar" que, em espaços diversos, promovem deslocamentos de sentido, fazendo parte de um processo discursivo (cf. ORLANDI, 2006). Dessa forma, se consideramos o corpo como materialidade significante, ele significa, mas não sem o sujeito. Podemos dizer que sujeito e corpo só significam no trabalho da linguagem, pela inscrição do sujeito em formações discursivas, que são o lugar material da ideologia, conforme Pêcheux (2009).

Diferentemente, para Foucault o corpo é regulado, vigiado e sobre ele (nele) atuam e transitam os mecanismos de poder. Nesse sentido, não só o que se diz do corpo, ou sobre 
ele, significa (ou ressignifica), os silêncios, as falhas e lacunas, a coerção e a "vontade de verdade" também significam e o constituem. Portanto, pensamos, nesse funcionamento, o silenciamento desses corpos e como, nesse processo de vigilância e poder, o mesmo corpo produz discursos e resiste. A resistência, de acordo com Foucault, sinaliza que não há apenas o vazio e a repressão, ao contrário, a resistência e a censura dos discursos possibilita que outros efeitos de sentido sejam produzidos, tendo em vista que não há produção de sentidos se não houver essas lutas. Essa transitoriedade do poder, segundo o autor, é atestada pelo fato de que:

[...] o poder não pára de questionar, de nos questionar; não pára de inquirir, de registrar, ele institucionaliza a busca da verdade, ele a profissionaliza, ele a recompensa. Temos de produzir a verdade como, afinal de contas, temos de produzir riquezas, e temos de produzir a verdade para poder produzir riquezas. $\mathrm{E}$, de outro lado, somos igualmente submetidos à verdade, no sentido de que a verdade é a norma; é o discurso verdadeiro que, ao menos em parte, decide; ele veicula, ele próprio propulsa efeitos de poder (FOUCAULT, 2002, p. 29).

Assim, produzir sentidos, discursos e verdades é uma necessidade humana, já que a linguagem, na perspectiva foucaultiana, não é arbitrária, mas está no mundo e dele faz parte, mostrando e ao mesmo tempo escondendo, propondo-se ao homem para que a decifre, sendo, portanto, parte da própria natureza do humano e do mundo (FOUCAULT, 1990, p. 51). O que fica de fora em Foucault é a história, diferentemente da perspectiva discursiva em que o sujeito, de acordo com Orlandi (2004/2012), é levado a interpretar a partir de 'gestos', e todo texto só significa se o inscrevermos na ordem da história.

Neste sentido, se entendemos as representações dos corpos como textos, a questão é como esses corpos se textualizam e que mecanismos instauram os dizeres sobre eles. Pela e na textualização, os efeitos de sentido dos corpos transferem-se, variam de acordo com a ideologia em funcionamento, com os discursos que retornam e com as memórias que ressoam e instauram a textualidade do corpo. Na materialidade analisada, os efeitos de sentido não se constituem por uma relação interna, mas na conjunção com outros corpos no espaço da cidade, que como corpo social não está desvinculada do sujeito. Um é constitutivo do outro pelo efeito de espelhamento, em que as partes se juntam, constituindo o todo, não como totalidade, mas como efeito de saturação e de fechamento.

Essas transferências e deslocamentos da materialidade do corpo constituem discursos, que funcionam em diferentes formações discursivas e derivam para outros efeitos de sentido ${ }^{2}$. Leandro Ferreira (2013, p. 132), diante de textualidades relacionadas ao corpo, propõe duas noções: o real do corpo e a memória do corpo. A primeira noção procede da psicanálise, como o real da língua, proposto por Milner, e vem a ser "o que falta, o que retorna, o que resiste a ser simbolizado", e possui, pelo simbólico, o sentido do impossível "que sem cessar subsiste". Leandro Ferreira (2013) propõe a noção real do corpo porque trabalhar o corpo como objeto simbólico demanda significá-lo como lugar discursivo, como espaço de significação do sujeito, antes que ele se signifique, como destaca Pêcheux (2009).

\footnotetext{
${ }^{2}$ De acordo com a teoria pêcheuxtiana, o discurso é efeito de sentido, na relação particular em que ele acontece a partir de processos.
} 


\section{CORPO E SUJEITO NO ESPAÇO: PRODUÇÃO E CIRCULAÇÃO DE SENTIDOS}

O corpus de análise recortado, neste trabalho, é uma publicação da revista Veja, Edição 2360, de 12 de fevereiro de 2014; mais precisamente, analisamos os modos como a chamada de capa da revista mobiliza e faz trabalhar efeitos de sentido e discursos outros, pela memória e pelo que retorna como memória. A materialidade significante é um textoimagem, estruturada por enunciados-imagem ${ }^{3}$ e enunciados verbais. Trata-se de um adolescente de 15 anos que foi preso por 'justiceiros', em um poste, com uma trava de bicicleta no pescoço. O adolescente está nu, sentado na calçada, e sobre seus olhos há uma tarja; já que se trata de um menor, ele tem direito ao anonimato, garantido pela justiça.

\section{Texto-imagem 1 - Revista Veja, Edição 2360, de 12/02/2014}

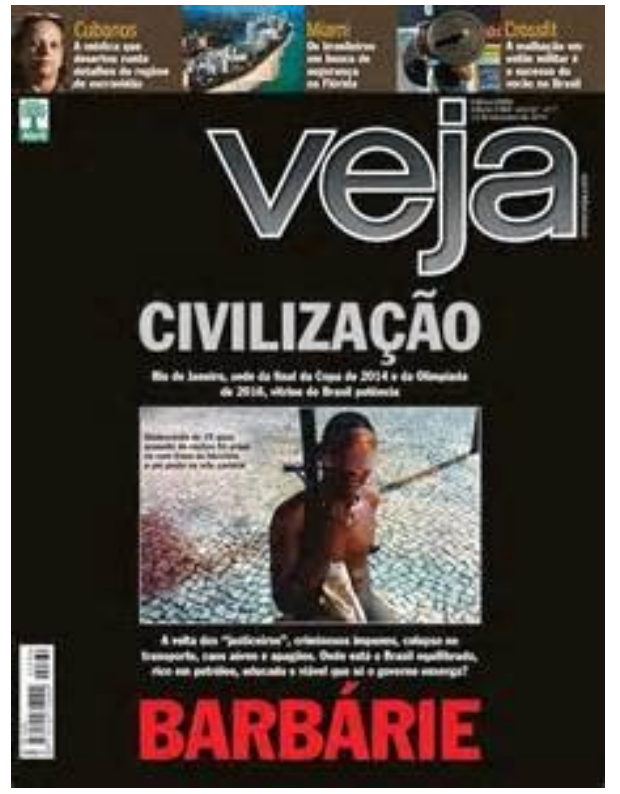

Fonte: $<$ http://veja.abril.com.br/acervodigital/home.aspx>.

O texto-imagem - capa da Revista Veja - aparece sobre fundo preto com destaque para as palavras 'civilização/barbárie', escritas em letras garrafais em cores contrastantes. As duas palavras podem ser lidas como antagônicas, já que ‘civilização' exclui o padrão de comportamento violento, em toda e qualquer situação, e ainda mais quando se trata de cidadãos, que, até prova em contrário, são sempre inocentes, como preconiza a lei. Esse antagonismo significa também pela sua incompletude, quando analisamos as cores que estruturam a capa da revista, como texto-imagem.

O termo 'civilização' - em cinza - e 'barbárie' - em vermelho sinalizam que os sentidos não estão, como preconiza Pêcheux (2009) e Orlandi (2002, p. 30), "só nas

\footnotetext{
${ }^{3}$ Entendemos os enunciados-imagem, a partir de Venturini (2009), como espaços interdiscursivos, porque significam pela memória, pela ideologia e pelo silêncio. Desse modo, um enunciado-imagem pode fazer parte de diferentes textos-imagem e vai significar pelas redes de memória constituídas e pela ideologia, que constitui evidências que encaminham para o discurso homogêneo, marcado pela saturação.
} 
palavras, nos textos, mas na relação com a exterioridade, nas condições em que eles são produzidos e que não dependem só das intenções dos sujeitos". Ancoradas no que diz Orlandi e no funcionamento do enunciado-imagem como espaço interdiscursivo, entendemos que pela cor cinza ressoa, como memória, o nebuloso, o passado, que por pouco não se apagou. Isso porque é, também, a mistura do branco e do preto, sendo, portanto, uma cor neutra. No texto-imagem em análise, porém, não há essa "neutralidade", pois ele convoca e faz trabalhar espaços de memória e discursos, que reorganizam a atualidade, conforme diz Pêcheux (2009). Por isso, instaura a contradição, tendo em vista que, no modelo de civilização, pensado no início da formação identitária nacional brasileira, o branco e cristão representavam o ideal de uma nação bem construída, segundo os moldes europeus. O negro e o pobre ficam fora dessa FD, em que se inscrevem os sujeitos da classe dominante.

Já pelo termo 'barbárie', em vermelho, ressoam efeitos de violência, de força bruta, de abuso de poder, de criminalidade, de ato covarde e truculento, podendo instaurar efeitos de sentido de força, de vitalidade e, também, de desejo. Esses efeitos de sentido decorrem do funcionamento do interdiscurso, como a memória do dizer, segundo Pêcheux (2009), o pré-construído, como algo que significa e fala antes em outro lugar. Pelo discurso transverso, ocorre o atravessamento de discursos que vêm de domínios distintos, ou seja, o domínio do discurso civilizatório e o da barbárie. Esse confronto entre o dito e o silenciado faz com que o passado se presentifique, sendo, portanto, ressignificado, reconstruído.

Esse jogo de memória dá visibilidade à instauração de redes de sentido e o repetível, como regularidade, pela qual o que foi dito antes, em outro lugar, funciona como memória e, também, como esquecimento, tendo em vista que a memória só existe e significa pelo esquecimento. Trata-se de "uma espécie de repetição vertical em que a própria memória esburaca-se, perfura-se antes de desdobrar-se em paráfrase", conforme Pêcheux (1999, p. 53). Nesse retorno do 'mesmo', a quebra da repetibilidade pode instaurar o acontecimento discursivo e inaugurar uma nova série, efeitos de sentidos outros, portanto, a polissemia.

Essa movência ${ }^{4}$ de sentidos e seus efeitos desencadeia um discurso outro, que atravessa a ambivalência das palavras civilização/barbárie, mas que não lhe é dissociado. A possibilidade de as palavras mudarem de sentido de acordo com as filiações ideológicas, as condições de produção de discursos constituem redes, e por essas redes discursos outros, como no texto-imagem destacado no Recorte 1:

\section{Recorte 1 - Brasil como sede dos jogos da Copa (2014) e Olimpíadas em 2016}

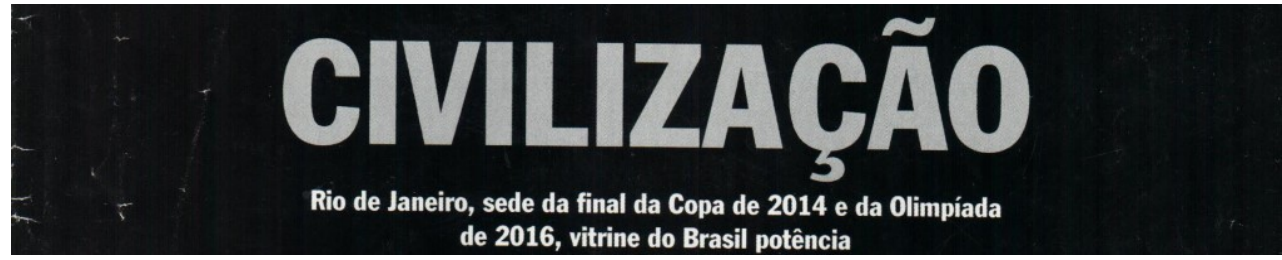

\footnotetext{
${ }^{4}$ Entendemos "movência" como a possibilidade de o sentido sempre poder ser outro, dependendo da posição-sujeito, das filiações ideológicas e das condições de produção. Ancoramo-nos em Orlandi (2012) quando destaca que as palavras 'não são indiferentes' aos sentidos, pois elas existem antes do sujeito, não dependendo dele, portanto, para significar.
} 
Podemos dizer que, na sequência discursiva acima, ressoam outros discursos na manifestação de "justiça" contra (ou não) o adolescente. O evento (Copa) ocorreu em fevereiro de 2014, período marcado por reclamações, exigências em torno das questões sociais e econômicas postas em xeque. Um desses eventos diz respeito ao Rio de Janeiro como sede da final da Copa Mundial, o que coloca a cidade como cartão postal do Brasil. A cidade foi escolhida para hospedar turistas e representar o perfil do Brasil, mostrando o país como uma "vitrine" e "potência". Esses dois textos-imagem funcionam como operadores de memória, pois, de acordo com Davallon (1999, p. 31), “a imagem, por poder operar o acordo dos olhares, apresentaria a capacidade de conferir ao quadro da história a força da lembrança". Neste sentido, os dois textos-imagem historicizam o dado e significam o fato, haja vista, ainda, o Brasil ser representado e reconhecido como o "país do futebol", digno de ser mostrado nas vitrines, como modelo de padrão de vida, de hospitalidade, de alegria e de despojamento. No entanto, no discurso da atualidade, 'vitrine' e 'potência' adquirem efeito de sentido de crítica, apagando a pretensa imagem de país desenvolvido e forte, vista e propagada pelo governo.

Nesse recorte, a palavra "vitrine", sinaliza para a constituição do Brasil como uma "potência" pelo olhar do outro. A veiculação do evento, na cidade sede dos jogos, acarretaria prejuízos, pois a cidade do Rio de Janeiro, imaginariamente bem organizada, não comporta e nem pode admitir atos de violência, que a inscrevem no lugar comum das cidades brasileiras, ou seja, também violenta, também perigosa, também lugar de 'justiceiros'. Sendo assim, "potência" instaura efeitos de sentido que produzem a contradição, pois aquilo que se toma imaginariamente como organizado significa de forma totalmente diferente, já que a violência instaura o caos e promove a desorganização.

Pelas memórias e discursos que ressoam, os enunciados destacados abrem, ainda, para outros efeitos de sentido, decorrentes da falta e da falha da língua como sistema, e como processo de significação pelos espaços vazios, lacunares, a serem preenchidos por discursos que vêm de outros lugares e estão/são sujeitos à interpretação. A prisão do "menino" pela população que circula, na orla, pode significar, discursivamente, como uma prática de justiça. Diante disso, cabe questionar: quem circula nesse espaço da cidade e quem lhes deu o direito de fazer justiça? Os sujeitos que o prenderam, desnudaram e o amarraram no poste ficam indeterminados, anônimos.

O contraditório instaura-se porque os sujeitos-cidadãos assumem a posição própria da polícia e do Estado, executando a justiça. E, se consideramos a linguagem em curso, o deslize dos sentidos e dos discursos que, nesse movimento, sempre podem ser outros, é necessário considerar o funcionamento de duas ou mais formações discursivas tendo em vista que no "país em que se prende um adolescente pela trava de bicicleta" por um "simples" roubo, é o mesmo país que não pune os "criminosos" que pertencem às classes dominantes e ocupam posições sociais de destaque, inclusive na organização das instituições sociais. Os não-punidos são aqueles que se inscrevem na formação discursiva antagônica ${ }^{5}$, a quem caberia manter a ordem e evitar roubos e corrupção.

\footnotetext{
${ }^{5}$ A contradição mostra o funcionamento de mais de uma posição-sujeito no interior de uma mesma FD, e o antagonismo indica a existência de mais de uma FD na formação social, instaurando efeitos de sentido em um mesmo sujeito. Esses dois funcionamentos sinalizam para a divisão e a heterogeneidade do sujeito.
} 
Nesse sentido, há o "funcionamento de um discurso verdadeiro" (FOUCAULT, 2002, p. 27), entendendo-se por 'verdadeiro' o discurso que advém daquele que tem o direito de dizer, ou seja, aquele que 'entra' na ordem do discurso porque possui um saber reconhecido que emana do poder das instituições. O poder em relação à materialidade analisada refere-se ao poder destacado pela revista como pertinente ao Estado, mas que falha, e ao falhar instaura a contradição. Na obra de Foucault (2002), a verdade é aquela proferida por quem está investido do poder de dizer. Trata-se da vontade de produzir uma verdade que submete os sujeitos e seus corpos ao processo de submissão ao poder. Esse desejo, segundo o autor, acontece na medida em que:

[...] Somos submetidos pelo poder à produção da verdade e só podemos exercer o poder mediante produção de uma verdade. [...]. Não porque certas pessoas querem dominar, mas como as coisas acontecem no momento, no mesmo nível, no procedimento da sujeição, processos contínuos e ininterruptos que sujeitam os corpos, dirigem os gestos, os comportamentos (FOUCAULT, 2002, p. 28-33).

Para Foucault, não há produção de verdade e de poder que não esteja perpassada pelas instituições. É, portanto, a presença do Estado na figura do seu governo, no caso da presidente Dilma, que é chamado a prestar contas, pois a ele cabe o poder de estabelecer e cumprir leis. Mas, a produção desses enunciados, ao mesmo tempo em que convoca essa presença, também a desautoriza. $\mathrm{O}$ enunciado "Onde está o Brasil equilibrado, rico em petróleo, educado e viável que só o governo enxerga?” Esse enunciado faz parte da reportagem “Jovem preso a um poste por 'justiceiros' perambula há dois anos pelas ruas do Rio", publicada na revista, e sinaliza para a desautorização que subverte o poder vertical que seria do Estado, que, não sendo "justo", permite que seus cidadãos "façam justiça". Naquilo que Foucault nomeia como resistência, essa possibilidade de expressão de poder está pulverizada e circula entre os sujeitos, não está centrada em uma única pessoa, já que esse poder só existe na prática.

Assim, podemos dizer que prender um adolescente em um poste na orla do Rio de Janeiro, às vésperas do evento Copa do Mundo, é, também, uma forma de resistência à ineficácia do poder do Estado, que não administra bem. Devido a essa má administração o país protagoniza "colapso no transporte, caos aéreo e apagões" - discursos que se presentificam na emergência do acontecimento e por isso mesmo o torna singular, rompendo com o regime de repetibilidade.

\section{Recorte 2 - Criminoso/justiceiro - riqueza e caos urbano}

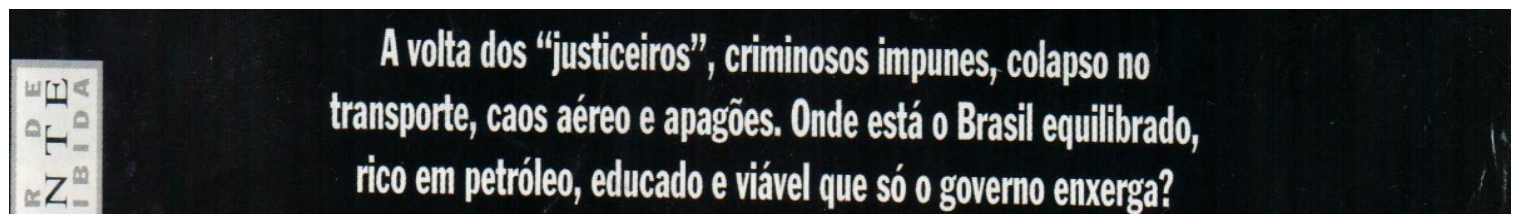


Além desses efeitos de sentido destacamos outros que ressoam pelo vigiar e pelo punir. A palavra 'criminosos', por exemplo, designa para Foucault a segregação - o contrário de ser bom, condição que, em sua arquegenealogia, é vista como um modelo já utilizado para segregar os corpos, para separar aqueles que seriam os corpos bons e dóceis, disciplinados, daqueles que não cumprem esse regime de disciplinarização. Esses que não cumprem são desviantes de uma norma de poder regulada e controlada. $\mathrm{Na}$ materialidade desse sujeito, essa disciplina se cumpre.

No regime de enunciabilidade, os sujeitos designados de "justiceiros", seguido da designação "criminosos impunes", convoca discursos e memórias e faz trabalhar, pelo que retorna como o já dito e significado, o Brasil como o país da impunidade, da violência e de leis ineficazes, que não protegem os cidadãos. Nesse caso, os sujeitos designados de "justiceiros" são cidadãos que merecem ser protegidos pelo Estado e, de outro, o 'menino infrator' e "criminoso", também merece a proteção do Estado, e isso não significa que não deva ir para cadeia. Mas quem deve colocá-lo lá é o Estado e não os cidadãos que se dão o direito de vigiar e punir, ocupando a posição que, de direito, seria do Estado.

Assim, a "marca divisória" (FOUCAULT, 1995, p. 231) entre criminosos/justiceiros é, nos estudos foucaultianos, uma categorização dos sujeitos, pois, funciona como um modo complexo de individualização e de objetivação, na medida em que lhes impõe uma "lei de verdade". Portanto, ao mesmo tempo em que a discursividade torna esse sujeito um objeto de discurso, impõe a ele as práticas de poder que, na forma de exercício e vigilância, o subjetivam.

Nesse sentido, para Foucault (2004b), em sua obra Vigiar e punir, num primeiro momento é do sujeito corpóreo que se exige a verdade, é nele e através dele que se manifesta o poder. É o suplício do corpo, a execução, a dor e a manifestação de um poder que pune. Mas não só isso; há também: "punições menos diretamente físicas, uma certa discrição na arte de fazer sofrer, um arranjo de sofrimentos mais sutis e despojados de ostentação. [...] Fazendo do supliciado um objeto de piedade e de admiração" (FOUCAULT, 2004b, p.12-14). Essa "tecnologia política do corpo" (2004b, p. 32), é um aparato de punição que vai além do sujeito, sendo um conjunto de elementos e de práticas que servem de sustentação para a transformação desses corpos em "objetos de poder". Nessa relação, não existe apenas $o$ sujeito, mas o coletivo, o corpo social que agrega e chama a todos, sendo o ato de punir e vigiar uma função generalizada. De acordo com Foucault:

[...] efetivamente a infração lança o indivíduo contra todo o corpo social; a sociedade tem o direito de se levantar em peso contra ele, para puni-lo. Luta desigual: de um só lado todas as forças, todo o poder, todos os direitos. E tem mesmo que ser assim, pois aí está representada a defesa de cada um. Constitui-se assim, um formidável direito de punir, pois o infrator tornase inimigo comum. Até mesmo pior que um inimigo, é um traidor, pois the desfere golpes dentro da sociedade. Um "monstro" (FOUCAULT, 2004b, p. 83).

Mas, no caso dessa materialidade, não é sobre o corpo, efetivamente, que o poder se exerce, mas passa por ele e deriva para outros dos quais são exigidos atos de poder, no caso o próprio governo nacional. Nesse sentido, não é o "menino" preso o "monstro", mas sim há uma inversão dessas posições, pois não é ele o criminoso, mas o próprio 
"governo". Assim, política e economia atuam sobre o corpo social, modificando-o e inscrevendo-o em determinados discursos de resistência aos modos de exercício do poder. Logo, no silenciamento e na coerção do corpo preso e punido do "adolescente", a escuta permanece e abre espaços para falhas, para cesuras e para a produção de outros sentidos.

E, se retomamos os pressupostos de Foucault (1995) de que não há poder sem resistências (no plural), no acontecimento discursivo analisado elas estão presentes, pois na materialidade do corpo preso (e sobre ele) ressoam e "ecoam" outros dizeres, outros sujeitos. Essas "vozes anônimas" exercem na discursivização do acontecimento o poder/saber/dizer. Segundo Foucault (2004a, p.37), esses sujeitos se inserem na ordem do discurso, respeitando aquilo que o autor denomina como determinante para as condições de funcionamento e permissão para que outros sujeitos tenham acesso aos dizeres. Isso porque "ninguém entrará na ordem do discurso se não satisfizer a certas exigências ou se não for, de início, qualificado para fazê-lo". Os discursos produzidos, portanto, não são fechados e proibidos, mas não são tão abertos assim - há uma limitação, uma dominação de sua aparição e a seleção dos sujeitos que falam, conforme Pêcheux (2009).

Para dar conta dos efeitos de sentido, já que o acontecimento determina o vigiar, o punir e também o significar, é preciso pensar a revista como veículo midiático. Segundo Benetti e Hagen (2010), a Veja é uma revista semanal que toma para si a responsabilidade de reformar o Brasil e tem como missão ser a maior e mais respeitada revista brasileira. A representação do veículo midiático sobre si mesmo tem a ver com o modo como ela veicula acontecimentos. Mesmo assim, discursivamente, esse controle em torno do dizer e dos efeitos de sentido a serem produzidos no leitor escapam à vontade do sujeito. Por isso, esses efeitos de sentido escapam à determinação institucional. Isso significa que os mecanismos de poder perpassam a esfera do público e do privado e instauram outras possibilidades de exercício desse mesmo poder, o que é pulverizado e distribuído, praticado.

No entanto, essa distribuição de poder não ocorre de modo aleatório: ele é verificável, mas invisível. Essa mesma invisibilidade permite-nos pensar a sua complexidade, pois, ele (o poder, ou "os poderes") não é apenas uma relação entre, mas um "modo de ação de alguns sobre outros", e ainda mais, se inscreve "num campo de possibilidade esparso que se apoia sobre estruturas permanentes". Também "não é da ordem do consentimento", nem um ato de "renúncia a uma liberdade", ou uma "transferência de direito". O exercício do poder definido por Foucault (1995, p. 244) consiste em "conduzir condutas" (grifos do autor) e em "ordenar a probabilidade".

Assim, o "governo" foi analisado e entendido por Foucault em seus estudos como sendo, desde o século XVI, o modo como era dirigida a conduta dos indivíduos e dos grupos, entre os quais estavam as crianças, as almas, as comunidades, as famílias, os doentes, entre outros. Governar seria, nesse sentido, "estruturar o eventual campo de ação de outros", sendo esse "modo de ação singular - nem guerreiro nem jurídico", o próprio governo, mais especificamente o "governo dos homens". E, nessa ação está incluída outra noção posta pelo autor: a liberdade. Nesse sentido, segundo Foucault (1995): 
[...] O poder só se exerce sobre "sujeitos livres", enquanto "livres" - entendendo-se por isso sujeitos individuais ou coletivos que têm diante de si um campo de possibilidade onde diversas condutas, diversas reações e diversos modos de comportamento podem acontecer. [...]. Não há, portanto, um confronto entre poder e liberdade, numa relação de exclusão (onde o poder se exerce, a liberdade desaparece); mas um jogo muito mais complexo: neste jogo, a liberdade aparecerá como condição de existência de poder [...] (FOUCAULT, 1995, p. 244).

A própria liberdade é uma condição para o exercício de poder, é ela que organiza os modos possíveis de ação de uns sobre outros, que condicionam as relações de poder, que estruturam as sociedades. Essas relações de poder são enraizadas no seio da mesma sociedade, sendo reguladas por formas e lugares de "governo" de uns homens sobre outros. Foucault (1995, p. 247) acrescenta, ainda, que "as relações de poder foram progressivamente governamentalizadas, ou seja, elaboradas, racionalizadas e centralizadas na forma ou sob a caução das instituições do Estado".

Na materialidade analisada, o corpo preso significa falta de liberdade - de dizer, de enunciar, de produzir sentidos, de produzir "verdades". Esse efeito se constitui porque "só o governo enxerga" esse país "equilibrado" e "rico". Na prática, os discursos não são entendidos como "verdadeiros", pela "população". Ocorre, nesse funcionamento, a atestação de que esse "governo" não está atuando na elaboração e na organização do poder sobre os sujeitos. O exercício de poder condiciona a verdade, enquanto produção exigida pela sociedade, uma vez que ela não está dissociada dos corpos dos sujeitos, que a constituem. E, na tentativa de compreensão dessa relação do corpo individuado e do corpo social, analisamos mais um recorte da mesma materialidade:

\section{Recorte 3 - Exposição (verbal) do corpo preso no espaço}

\section{Adolescente de 15 anos acusado de roubos foi preso nu com trava de bicicleta a um poste na orla carioca}

No recorte 3, há a referência ao espaço urbano como local de mobilização de sentidos e de corpos, de produção de discursos. A cidade é constitutiva do sujeito, eles não existem separadamente. Nesse sentido, pensar o lugar, segundo Scherer (2008), é também pensá-lo em seus domínios e fronteiras, em seus modos de repetição tomados por regularidades; de suas formulações, e de certa regularização, sendo, portanto, um "lugar de formulação, produção e circulação de discurso e de lugar" (SCHERER, 2008, p. 132). Isso significa que o lugar funciona sempre em relação a, constituindo-se como um "entrelugar", espaço de falhas, de lacunas; não é pleno e saturado, mas simbólico e histórico, sempre constante e mutável, aberto a deslocamentos e fragmentações.

Segundo Pêcheux (1999, p. 56), o espaço como mobilização de sentidos e produção de discursos é, antes de tudo, "um espaço móvel de divisões, de disjunções, de deslocamentos, de retomadas, de conflitos de regularização [...] Um espaço de desdobramentos, réplicas, polêmicas e contra-discursos." É assim que, no espaço da cidade, aparentemente homogêneo, há o atravessamento de discursos, de enunciados e de 
saberes que, textualizados pelos corpos dos sujeitos que a constituem, transformam-na em espaço aberto, não pleno, sem bordas delimitadas, enfim, lacunar. Ocupar esse espaço é também escrever, demarcar e produzir - ação histórica do sujeito que o faz pela linguagem, na materialidade dos discursos que significam as cidades; não apenas o espaço urbano, mas a urbanidade pensada na relação direta sujeito/língua/história. Quanto ao corpus analítico, dizemos que o discurso veiculado constitui a cidade do Rio de Janeiro, na sua pluralidade, anteriormente descrita, nas suas ressignificações, nas suas redes de memória. Por essas redes de memória constituem-se as marcas de sujeitos e de discursos, os quais, em outro tempo, já circularam, do que emerge um discurso outro, presente no discurso da atualidade, aparentemente linear.

A orla carioca - delimitação espacial da transitoriedade dos turistas que olham a "vitrine" do Brasil - dá visibilidade (ou silencia), não apenas, a representação imaginária do país, mas, também, a seus contradiscursos, a suas contradições, a suas moventes retomadas, nas quais espaço, tempo e sujeito significam de modo sempre descontínuo, como prática humana - portanto, o lugar de falha, de produção de sentidos.

\section{CONSIDERAÇÕES FINAIS}

Ancoradas nos aportes teóricos da AD pêcheuxtiana e nos ditos de Foucault, pudemos, a partir da análise do discurso dos textos-imagem, acima expostos, destacar o modo como, na produção e veiculação de um determinado texto (tomado como objeto simbólico), outros textos e discursos são produzidos e deslizam para sentidos outros que não estão presos e fechados à materialidade textual, mas que escapam aos seus limites e falhas. Os sentidos se movem e significam pelo atravessamento da memória no eixo da formulação. Neste sentido, neste trabalho, percebemos como uma imagem possibilita a produção de uma série de enunciados que remetem não apenas ao acontecimento referido, mas às condições de produção que refletem o contexto sócio-histórico de produção da materialidade.

Essa movência de efeitos de sentido, nos discursos sobre um corpo preso e punido em plena orla carioca, reclama e faz funcionar a resistência de poder e de redes de memória que inscrevem esse acontecimento em um arquivo. E, mesmo que esse corpo esteja submetido ao poder e dele reclame a sua existência, nas práticas sociais desses sujeitos os sentidos não são únicos e nem homogêneos, mas transitórios.

Assim, retomando Orlandi (2002), dizemos que, se os sentidos são múltiplos, é porque o silêncio também o é, sendo, igualmente, constitutivo desses sentidos, uma vez que ele dá visibilidade ao fato de que não há dizer que não estabeleça sentidos outros, ecoando continuamente no sujeito. Dessa forma, se falando significamos, também o fazemos pelo corpo, como materialidade significante. Ocupar o lugar de, assumir uma determinada posição- sujeito em uma rede de enunciados, filiados a uma formação discursiva e a regimes de historicidade é uma constante no trabalho do sujeito, e aí o sujeito é textualizado em/pelo seu corpo, ocupando um lugar social que, mesmo 'parecendo' individual, encaminha para a relação direta com outros corpos que o integram e constituem o imaginário da cidade. A cidade funciona não como um espelho, mas como 
texto dado a ler, como espaço simbólico de atravessamento de discursos e de enunciados que delimitam os saberes e poderes/dizeres desses sujeitos, que, inevitavelmente, permanecem na censura velada de seus corpos, de suas significações materiais, em seus respectivos espaços. Pensar o corpo desvinculado da relação sujeito/mundo e história é negar-lhe sua significação, seus limites de dizer e suas possibilidades de movência.

Diante do que foi dito, sublinhamos que não apenas significamos os discursos enunciados, enquanto sujeitos históricos e simbólicos; o que fazemos liga-se ao movimento do corpo, porque nos identificamos nele e com ele nos agrupamos ou desvinculamos de grupos, textualizamo-nos. Deslocando o corpo o sujeito significa a si e ao outro, numa relação contínua de sentidos que permitem ao mesmo sujeito ser o lugar de sua própria subjetividade. Ressignificar os corpos é uma das possibilidades de compreender o humano em sua forma política e social, numa filiação a discursos plurais que permitem as formulações do sujeito, em suas condições específicas, em diferentes possibilidades de dizer, de ser. E nessas relações não há simplesmente um embate de corpos abstratos, mas também relações de poder que se estabelecem e explicam a história do homem - poder que não é único e linear, mas plural e provisório.

\section{REFERÊNCIAS}

BENETTI, M.; HAGEN, S. Jornalismo e imagem de si: O discurso institucional das revistas semanais. Revista Estudos em Jornalismo e Mídia, v. 7, n. 1, p. 123-135, jan.-jun. 2010.

CERTEAU, M. de. A invenção do cotidiano. v. 1: Artes de fazer. Trad. Ephraim Ferreira Alves. Petrópolis, RJ: Vozes, 1994.

COURTINE, J.-J. História do corpo: as mutações do olhar: O século XX. Sob a direção de Alain Corbin. Trad. e revisão Ephraim Ferreira Ales. 3. ed.. Petrópolis, RJ: Vozes, 2009.

DAVALLON, J. A imagem, uma arte de memória?. In: ACHARD, P. et al. Papel da memória. Trad. José Horta Nunes. Campinas, SP: Pontes, 1999. p. 23-37.

FOUCAULT, M. As palavras e as coisas. Uma arqueologia das ciências humanas. 5. ed. São Paulo: Fontes, 1990.

O sujeito e o poder. In: RABINOW, P.; DREYFUS, H. Michel Foucault. Uma trajetória filosófica. Rio de Janeiro: Forense Universitária, 1995.

Em defesa da sociedade. Curso no Collège de France (1976-1976). Trad. Maria Ermantina Galvão. São Paulo: Martins Fontes, 2002.

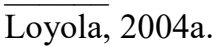

A ordem do discurso. 10. ed. Trad. Laura Fraga de Almeida Sampaio. São Paulo: Edições

Vigiar e punir. O nascimento da prisão. 29. ed. Trad. Raquel Ramalhete. Rio de Janeiro: Vozes, 2004b.

Microfísíca do poder. 25. ed. São Paulo: Graal, 2008.

A arqueologia do saber. Trad. Luiz Felipe Baeta Neves. 7. ed. Rio de Janeiro: Forense Universitária, 2010

LEANDRO FERREIRA, M. C. Discurso, arte e sujeito e a tessitura da linguagem. In: INDURSKY, F.; LEANDRO FERREIRA, M. C.; MITTMANN, S. (Org.). AD: O acontecimento do discurso no Brasil. Campinas: Mercado das Letras, 2013.

ORLANDI, E. P. As formas do silêncio: no movimento dos sentidos. Campinas, SP: Unicamp, 2002. Interpretação: autoria, leitura e efeitos do trabalho simbólico. Campinas, SP: Pontes, 2004. . À flor da pele: indivíduo e sociedade. In: MARIANI, B. A escrita e os escritos: reflexões em análise de discurso e psicanálise. São Carlos: Claraluz, 2006. Análise de Discurso: princípios e procedimentos. 4. ed. Campinas, SP: Pontes, 2012. 
PÊCHEUX, M. Análise Automática do Discurso. In: GADET, F.; HAK, T. (Org.). Trad. Bethania Mariani et al. São Paulo: Unicamp, 1997.

Pontes, 1999

Papel da memória. In: ACHARD, P. et al. Papel da memória. Trad. Horta Nunes. Campinas:

O discurso: estrutura ou acontecimento. 3. ed. Trad. Eni Orlandi. Campinas, SP: Pontes, 2002.

Semântica e discurso. Uma crítica à afirmação do óbvio. Trad. Eni P. Orlandi. et al. 4. ed. São

Paulo: Unicamp, 2009.

SCHERER, A. Dos domínios e das fronteiras: o lugar fora do lugar em outro e mesmo lugar. In:

SARGENTINI, V.; GREGOLIN, M. do R. (Org.). Análise do Discurso. Heranças, métodos e objetos. São Paulo: Claraluz, 2008.

VEJA. Ed. 2360, 12 fev. 2014. Disponível em: <http://veja.abril.com.br/acervodigital/home.aspx>.

VENTURINI, M. C. Imaginário urbano: espaço de rememoração/comemoração. Passo Fundo, RS: Editora da UPF, 2009.

Recebido em: 30/08/15. Aprovado em: 01/03/16.

Title: The body in the urban space: between discipline, punish and signify

Authors: Maria Cleci Venturini; Marilda Aparecida Lachovski

Abstract: The body, as discursive object is a significant materiality, in which return and resound memories and discourses, introducing identifying processes. In this way, we think how the body, in the urban space, has been represented and understood as textuality. We do this by two points of view: by Foucault and by Pêcheux, emphasizing that the discourse is the meeting point between both. On one hand, we attempt for a disciplined and punished body and for a coercive society that authorizes, by itself, the justice; and on the other hand, for the ideology that naturalizes the discipline and punish, and the memories that means discursive practices around of to 'make' justice, judge and condemn. Thereunto, we take a part of Veja magazine cover (February, 2014), in view of the disciplined and punished body and the body that means by memory and ideology in a society that represents itself as righteous, but not always just.

Key words: Discourse. Body. Historicity. Memory. Power.

Título: El cuerpo en el espacio urbano: entre disciplina, punición y significación Autores: Maria Cleci Venturini; Marilda Aparecida Lachovski

Resumen: El cuerpo, como objeto discursivo, es una materialidad significante por medio de la cual retornan y resuenan memorias y discursos, instaurando procesos de identificación. En este sentido, se piensa en las formas como el cuerpo viene siendo representado y leído, en el espacio urbano, como una textualidad. Se hace ello por medio de dos miradas teóricas: de Foucault y de Pêcheux, resaltando que el discurso constituye el punto de encuentro entre los dos. De un lado se atenta para el cuerpo vigiado y punido, y para una sociedad coercitiva, que se autoriza hacer justicia, y de otro para la ideología que naturaliza el vigiar, el punir y las memorias que significan las prácticas discursivas alrededor del 'hacer' justicia, del juzgar y del condenar. Para ello se recorta la cubierta de la revista Veja (febrero de 2014), teniendo en vista el cuerpo vigiado y punido y el cuerpo que significa por la memoria y por la ideología en una sociedad que se representa como justiciera, pero ni siempre justa.

Palabras-clave: Discurso. Cuerpo. Historicidad. Memoria. Poder.

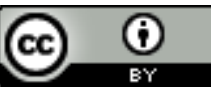

Este texto está licenciado com uma Licença Creative Commons Atribuição 4.0 Internacional. 